\title{
Identifying of Intrapreneurship Behaviors: Case of Country in Transition Economy
}

\author{
Mahmood Monfared ${ }^{1}$, Alireza Khorakian ${ }^{2}$, Ali Shirazi ${ }^{2} \&$ Yaghoob Maharati $^{2}$ \\ ${ }^{1}$ Ph.D Student in Management, Ferdowsi University of Mashhad (International campus), Iran \\ ${ }^{2}$ Associate Professor, Ferdowsi University of Mashhad, Mashhad, Iran \\ Correspondence: Alireza Khorakian, Associate Professor, Ferdowsi University of Mashhad, Mashhad, Iran. Tel: \\ 98-51-38805361. E-mail: a.khorakian@um.ac.ir
}

\author{
Received: February 4, 2019 Accepted: March 5, $2019 \quad$ Online Published: April 11, 2019 \\ doi:10.5539/mas.v13n5p1 URL: https://doi.org/10.5539/mas.v13n5p1
}

\begin{abstract}
Successful companies figure out that the most important elements in the organization are the ability to use the creativity of managers and employees through the recognition of their behaviors. One of the most important strategies for developing intrapreneurship in organizations is to improve and enhance the intrapreneurial behavior of employees, but what is deduced from the review of the history of the research is that most of the studies in the field of personality of entrepreneurs pointed to their characteristics and the type of properties is fewer studies, especially in developing countries and transition economies. The research is part of a series of research that seeks to identify and explore the components of intrapreneurial behavior in the organizations of Iran as a developing country, which is one of the economies in transition. This research is qualitative research in which a thematic analysis approach has been used. The statistical population of this project is selected among 170 competent firms. The findings of the study showed that 27 components of intrapreneurial behaviors in the organization, including 10 personality-based intrapreneurial behaviors and 17 effective entrepreneurial behaviors affected by the environment.
\end{abstract}

Keywords: intrapreneurship, intrapreneurial behavior, transition economy

\section{Introduction}

\subsection{Expression of the Research Problem}

Transition economy is an economic system that changes from a planned economy to a market economy. Transition economies are undergoing a series of structural changes that seek to develop market-based institutions (Edgar, 1994). According to the United Nations, "The world economic situation and prospects 2018" countries in the world that have a transition economy. (New York, 2018). In the transition economy, what is important is the role of market economics and market-based competition, with a particular emphasis on organizational intrapreneurship. Organizational intrapreneurship is a strategic tool for economic development, and organizations use this strategy in response to the three needs imposed on them: 1 . The rapid growth of new competitors 2 . Creating a sense of distrust to traditional management practices in organizations 3. The separation of the best workforce from organizations and their action for independent intrapreneurship, which has led organizations to become more and more vulnerable to risk, and organizational managers are constantly thinking about finding a solution to get rid of this problem to be able to maximize their profitability by more adaptation with ever-changing status of the economy and by them more to changing economic conditions and taking risks and fostering innovation in products and services. Hence, as time goes by, the importance of innovative human resources in organizations is becoming more and more evident; those who create the process of innovation in the field of global competition that creating new ideas and identifying new markets for investment would cause the improvement of life quality of people in the community and the growth of the economic structure. Therefore, it is necessary for the managers to have a thorough and comprehensive evaluation of organizational intrapreneurship to be able to react quickly to adverse environmental changes and successfully pass through their own crises and become a leading organization and entrepreneur. In 2013, Business Venture Magazine published its special issue on "frustrating poverty", failure of economic development, and named the organizational intrapreneurship as a solution to the challenges of economic development (Munoz, 2018). There is evidence that organizational intrapreneurship helps managers renew their business and innovates and increases their performance and business (Elert, 2015). According to Morrison (2011), 
the process of intrapreneurship is rooted in intuition, community, and culture. Intrapreneurship enjoys from some applications beyond mere economic performance, combining material and non-material factors as well as "pragmatism" and "idealism". One of the differences between personal and organizational intrapreneurship is that personal entrepreneurial measures are "constructive," while organizational Intrapreneurship often refers to "retrieval," and recovery measures are used are usually used in facing with "stagnation" in large organizations. Organizational intrapreneurship can improve growth and innovation in a traditional organization (Fry, 1993). The concept of Organizational intrapreneurship has evolved through innovation, strategic change, and strategic management and focuses on intrapreneurial activities in an organization to enhance the performance (Kuratko, 2005). Since the early 1980s, the intrapreneurship and the emphasis of organizations on innovation have survived and competed with entrepreneurs with little capital in the market, leading the entrepreneurial activities inside the organizations. Theoretical research emphasizes the importance of human capital in organizational intrapreneurship (Parker, 2011; Claycomb, 2005; Audretsch, 2001). Human capital has two features of general and specific; the general feature of human capital is the skill, knowledge, experience, and specialty of the staff, but the specific character of human capital is obtained through training (Anton, 1995; Zucker, 1998; Freeman, 2007 ) general and specific human resources show that human resources are an opportunity that can be used as an investment in the company (Klepper, 2001; Freeman, 2007; Helfat, 2002). The important point here is that firms can utilize the general characteristics of human resources (skills, knowledge, experience, expertise)by using the specific feature (through training) of human resources for their own purposes. The specific feature of human capital can affect the development path of a new idea and lead to innovation that can be used within the company (Davidsson, 2006; Kim, 2006). In such cases, organizational intrapreneurship is a logical option because Drucker believes that organizational intrapreneurship is a behavioral model, not a personal characteristic that can be trained to employees. The conducted studies have shown that most of the world's most well-known companies, such as Apple and Google, use this particular feature of their human capital to utilize the general characteristic of their human resources (Kuratko, 2015; Brown, 2011; Gunther, 2010). These companies are studying the specific characteristics of human resources to determine some methods to support the entrepreneurial environment of their organization (Govindarajan, 2005). A company like Apple, for example, is investigating "How the death of Steve Jobs could affect the internal creativity of the firm" (Kuratko, 2012; Bedigian, 2011), In fact, successful companies seek to create an entrepreneurial environment for entrepreneurial behaviors. One of the most important ways of developing entrepreneurship in organizations is to develop and promote entrepreneurial behavior of individuals. Intrapreneurial behavior is directly associated with knowledge, skills, human experiences, family conditions, personality traits, and environmental and social conditions. Over the past few decades, theoretical and empirical studies have suggested that intrapreneurship is a process used in a variety of fields and is examined from a different perspective, not merely from the point of view of its economic benefit for the organization. (Zampetakis, 2007). One of these areas is intrapreneurial behavior, intrapreneurial behavior covers all actions performed by the members of an organization and is associated with exploring, evaluating and utilizing the entrepreneurial opportunities (Kuratko, 2005).

\subsection{Theoretical Foundations}

\subsubsection{Intrapreneurship (Organizational Entrepreneurship)}

The inadequacy of traditional management practices, intense competition between organizations, and the rapid growth of small firms have attracted serious attention from organizations to innovation, thus trying to bring creative and intrapreneurial individuals who were the main creators of new services in the organization. Encourage and persuade them to stay in the organization and realize their ideas in the organization. Pinkat called these individuals an intrapreneurial organization, in 1985 he devised a combination of the words "Corporat", "Entrepreneurship" and "Intra" the word "Intrapreneurship". At first, it was believed that entrepreneurs themselves own and own their own business, but today they believe that entrepreneurs may be hired by companies and are born from organizational entrepreneurs. Organizational intrapreneurship is the process that generates services or productive processes by creating an intrapreneurial culture in an organization (Fry, 1993). The main objective of enterprise intrapreneurship is to create a dynamic organizational structure and culture (Ergun, 2004). Organizational intrapreneurship is the process of creating new abilities and capacities by hunting opportunities and presenting new ones and transforming those ideas into tangible results and new abilities. In other words, enterprise intrapreneurship is a collection of activities that has the resources and organizational support to achieve innovative results. The intrapreneurial process in companies plays an important role in formulating strategies and innovation. Having this approach and way of thinking in organizational individuals causes the organization to seek new opportunities in the market or seek to attract customer satisfaction is through customer satisfaction (Mazzarol, 2006). In the research (2011, Parker), Organizational intrapreneurship describes organizational organization as an 
innovative solution and solution to traditional problems and a new concept for interaction and change within the organizational climate. According to this definition, an enterprise entrepreneur directly the sequence is the strength and integrity of the system, while organizational development and organizational change are a competitive advantage in the sequence of inventing organization and restructuring.

\subsubsection{Intrapreneurship Behavioral in the Organization}

Studies have shown that large companies like "Apple" and "Google" have identified the most important elements within their organization to enhance their creativity, staff, and managers. Some employees have contributed to the compensation system, the nature of management, and management autonomy to encourage intrapreneurial behaviors. Covin and Quarto discuss that at high levels of organizational management, it represents a strategic goal and purpose along the lines of intrapreneurial activities for their company to compete successfully and this concept reflects the managers' eagerness to look for their controlled practices to promote entrepreneurial activities within the organization and define the entrepreneurial strategy based on entrepreneurial behavior that is constantly rejuvenated by the organization (Kuratko, 2015). Intrapreneurial behavior refers to the tendencies and behaviors that help companies change their resources in expanding resources and tracking new opportunities.

Organizational entrepreneurship plays a leading role in the transitional economy because it is an economic system that changes from a planned concentrated economy to the market economy. Transition economies incur a series of structural changes that seek to develop market-based institutions. These include the liberalization of the economy, through which the prices instead of being determined by a central planning organization will be assigned to the market forces (Edgar, 1994). The importance of small and medium-sized enterprises is not limited to forming the economy and economic progress, creating employment, increasing competition, and reducing inequality but it is different depending on the infrastructure and institutions of different countries. Entrepreneurship in transitional economies has been explicitly studied due to its characteristics, such as the permanent change in the laws and interactions between the entrepreneur, the behavior of the firm, and the economic environment. According to the opinion of most the leaders in this field, small and medium-sized firms, due to their agility against regulations, are the way out of many problems created during the change of the economic system (xheneti, 2017).

\section{Method}

The purpose of this research is to explore the components of intrapreneurial behavior in the organization by designing the main question of "what are the components of intrapreneurial behavior in the organization?" Or indeed what entrepreneurs are doing in the organization and which activities lead to entrepreneurship.

This research is qualitative using the thematic analysis method, which is one of the fundamental methods of qualitative analysis different from other conventional methods that seek to describe the patterns of qualitative data, like phenomenological analysis method, foundation data theory, discourse analysis, and content analysis. One of the methods which is somehow similar to the thematic analysis is content analysis. However, the content analysis focuses more on micro levels, often shows the frequency of data, and makes quantitative analysis of qualitative data possible. One of the problems with the content analysis is that it usually does not pay or pay little attention to the data context and this will considerably reduce the richness of the data. But in analyzing the theme, the unit of analysis is more than a word or term, and more attention is paid to the context of the data and their nuances. Also, the analysis of the theme goes beyond counting obvious words and phrases and focuses on the recognition and explanation of explicit and implicit ideas. Then, the main thematic codes are used for more in-depth analysis of the data. Within the thematic analysis, it is possible to use the relative frequency of the content to compare them and to provide the matrix of the content and the plotting of the theme network (Namey, 2007). Since in the analysis of a theme, instead of particular data, certain themes or patterns are considered, such as personal interviews or various interviews with a person about case study or autobiography, and Since the present study is seeking for the components of entrepreneurial behavior of employees, considering that the information was gathered through firsthand interviews with an emphasis on their data context and their subtleties. The organizations studied in this study were 170 active and competent companies in Iran. Considering that the mentioned criteria were considered for selecting the sample, the sampling method was non-random purposeful. The sample size in qualitative studies continues until it reaches the saturation of information. Information saturation is usually a guide to decide how much interviewing is enough. This means that if at the time of data collection no new information is added and the sampling ends when the researcher at the time of collecting and updating information extracted only encounters with previous entry to verify and authenticate (Gholami, 2011). In the study, the researcher reaches the information saturation after interviewing 21 intrapreneurial organizations. Interviews were conducted with 21 participants, of which 17 were male and 4 were women. To analyze the interviews, there are various methods for analyzing the subject, each of which follows certain processes. In this research, the combination of King and Haroux (2010), 
Brown and Clark (2006) and Atride and Stilling (2001), a stepwise and comprehensive process were used for analyzing the subject. This process is based on three, six, and twenty steps. The complete analysis of the subject matter can be divided into three phases: 1) the analysis of the text 2) narration of the text 3) integration and reintegration of the text. Four validation measures were used to determine the validity and reliability of the qualitative research, namely reliability, validity, authenticity, and transmission capability. And to achieve a more favorable outcome in analyzing data, the latest version of the Nvivo Software was used in (Table 1).

Table 1. Demographic Characteristics

\begin{tabular}{lll}
\hline Gender & Frequency & Percentage \\
\hline Female & 17 & 81 \\
Male & 4 & 19 \\
Age & Frequency & Percentage \\
$\mathbf{2 0 - 3 0}$ & 3 & 14.2 \\
$\mathbf{3 1 - 4 5}$ & 16 & 76.3 \\
$\mathbf{4 6 - 6 0}$ & 2 & 9.5 \\
\hline
\end{tabular}

\section{Results}

After performing interviews and collecting the basic information, using the method of thematic analysis, data analysis was performed using various software, such as Nvivo. Also, for the adequacy of the research variables and whether the obtained criteria are suitable variables for analyzing entrepreneurial behaviors in the organization or not, the KMO index and the Bartlett test were used. The KMO index is an indicator of the suitability of sampling variables. This index is in the range of 0 to 1 . If the value of the index is close to one, the data are suitable for exploratory factor analysis, otherwise, (typically less than 0.5 ) the results of exploratory factor analysis for the given data are not appropriate (Wixon \& Watson, 2001; Plant, 2009). In this study, the results of the Bartlett and $\mathrm{KMO}$ tests indicate that the values of both indicators are at a desirable level. The KMO criterion for the variables is more than 0.5 and the significance of the Bartlett test is less than 0.05 , which indicates that the items extracted from this study are suitable variables for analysis, so they correctly compute the component of the entrepreneurial behavior in the organization. Also, items with a subscription of less than 0.3 were excluded from the analysis. The results are presented in (Table 2).

Table 2. Exploratory Factor Analysis

\begin{tabular}{|c|c|c|c|c|c|c|c|}
\hline Variable name & Items & $\begin{array}{c}\text { Factor } \\
\text { loadfirst stage }\end{array}$ & $\begin{array}{c}\text { Factor load } \\
\text { after removing } \\
\text { variables }\end{array}$ & $\begin{array}{c}\text { Significance } \\
\text { of Bartlett's } \\
\text { Test }\end{array}$ & $\begin{array}{c}\text { Degrees of } \\
\text { freedom }\end{array}$ & $\begin{array}{l}\text { Approximately } \\
\qquad \mathbf{2 x}\end{array}$ & $\begin{array}{c}\text { KMO sampling } \\
\text { adequacy } \\
\text { criterion }\end{array}$ \\
\hline \multirow{3}{*}{$\begin{array}{c}\text { Human and right } \\
\text { behavior }\end{array}$} & ENS1 & 0.466 & 0.466 & \multirow{5}{*}{0.000} & \multirow{5}{*}{6} & \multirow{5}{*}{98.835} & \multirow{4}{*}{0.852} \\
\hline & ENS2 & 0.690 & 0.690 & & & & \\
\hline & ENS3 & 0.532 & 0.532 & & & & \\
\hline \multirow{7}{*}{ Active listening } & ENS4 & 0.572 & 0.572 & & & & \\
\hline & GOS1 & 0.412 & 0.412 & & & & \multirow{5}{*}{0.672} \\
\hline & GOS2 & 0.380 & 0.380 & \multirow{4}{*}{0.000} & \multirow{4}{*}{10} & \multirow{4}{*}{146.551} & \\
\hline & GOS3 & 0.715 & 0.715 & & & & \\
\hline & GOS4 & 0.568 & 0.568 & & & & \\
\hline & GOS5 & 0.392 & 0.392 & & & & \\
\hline & NAZ1 & 0.335 & 0.330 & \multirow{2}{*}{0.000} & \multirow[b]{2}{*}{6} & \multirow{2}{*}{60.474} & \multirow{2}{*}{0.795} \\
\hline Order and coordination & NAZ2 & 0.462 & 0.586 & & & & \\
\hline
\end{tabular}




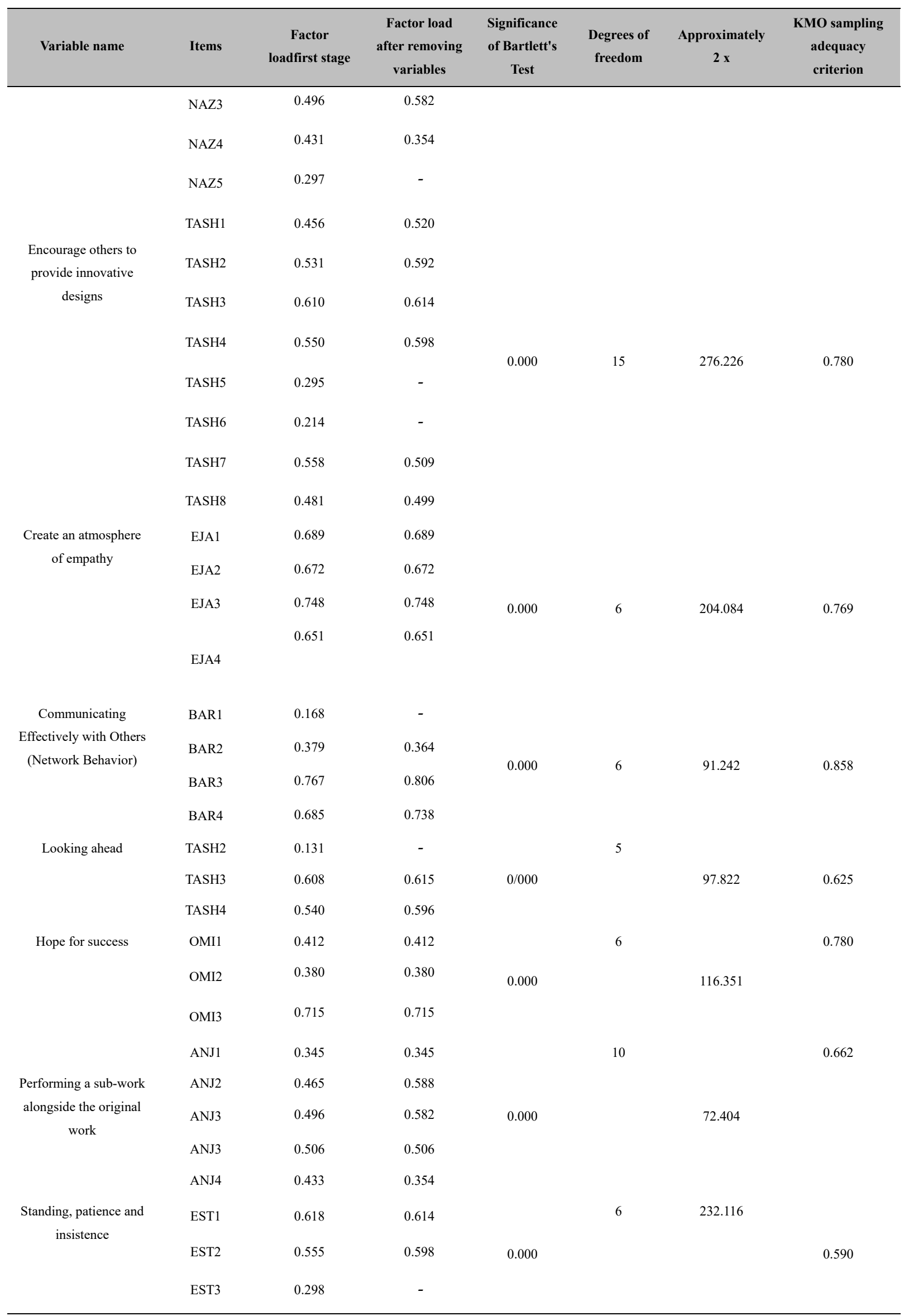




\begin{tabular}{|c|c|c|c|c|c|c|c|}
\hline Variable name & Items & $\begin{array}{c}\text { Factor } \\
\text { loadfirst stage }\end{array}$ & $\begin{array}{c}\text { Factor load } \\
\text { after removing } \\
\text { variables }\end{array}$ & $\begin{array}{c}\text { Significance } \\
\text { of Bartlett's } \\
\text { Test }\end{array}$ & $\begin{array}{l}\text { Degrees of } \\
\text { freedom }\end{array}$ & $\begin{array}{l}\text { Approximately } \\
\qquad \mathbf{2 x}\end{array}$ & $\begin{array}{c}\text { KMO sampling } \\
\text { adequacy } \\
\text { criterion }\end{array}$ \\
\hline \multirow{4}{*}{$\begin{array}{l}\text { Independent work in } \\
\text { the form of group work }\end{array}$} & MOS1 & 0.390 & 0.390 & & 4 & & 0.650 \\
\hline & & 0.725 & 0.725 & & & & \\
\hline & MOS2 & & & 0.000 & & 216.266 & \\
\hline & YAD1 & 0.545 & 0.596 & & 10 & 91.231 & \\
\hline \multirow{4}{*}{$\begin{array}{l}\text { Learning and teaching } \\
\text { through in-service } \\
\text { training }\end{array}$} & YAD2 & 0.632 & 0.632 & & & & \\
\hline & YAD3 & 0.430 & 0.430 & 0.000 & & & 0.780 \\
\hline & YAD4 & 0.390 & 0.390 & & & & \\
\hline & YAD5 & 0.362 & 0.362 & & & & \\
\hline \multirow{2}{*}{$\begin{array}{c}\text { Use of new science and } \\
\text { technology }\end{array}$} & EST1 & 0.635 & 0.635 & & 3 & 212.082 & 0.625 \\
\hline & EST2 & 0.505 & 0.556 & $0 / 000$ & & & \\
\hline \multirow[t]{3}{*}{ Monetize activities } & FAL1 & 0.535 & 0.535 & & 3 & 60.221 & 0.575 \\
\hline & FAL2 & 0.615 & 0.615 & $0 / 000$ & & & \\
\hline & FAL3 & 0.522 & 0.522 & & & & \\
\hline \multirow[t]{2}{*}{ Ready to accept change } & AMA1 & 0.610 & 0.610 & 0000 & 6 & 01242 & 0.625 \\
\hline & AMA2 & 0.582 & 0.582 & 0.000 & & 91.242 & \\
\hline \multirow{6}{*}{$\begin{array}{l}\text { Combining knowledge } \\
\text { and skills and } \\
\text { experience }\end{array}$} & TAL1 & 0.432 & 0.445 & & 9 & 64.223 & 0.745 \\
\hline & TAL2 & 0.390 & 0.390 & & & & \\
\hline & TAL3 & 0.275 & - & & & & \\
\hline & TAL4 & 0.562 & 0.562 & 0.000 & & & \\
\hline & TAL5 & 0.415 & 0415 & & & & \\
\hline & TAL6 & 0.546 & 0.546 & & & & \\
\hline \multirow{2}{*}{$\begin{array}{l}\text { Learn specialized work } \\
\text { skills }\end{array}$} & FAR1 & 0.392 & 0.392 & & 3 & 60.256 & 0.583 \\
\hline & FAR1 & 0.395 & 0.380 & 0.000 & & & \\
\hline \multirow{3}{*}{$\begin{array}{l}\text { Time out to solve the } \\
\text { problem }\end{array}$} & VAG1 & 0.715 & 0.715 & & 6 & 123.210 & 0.645 \\
\hline & VAG2 & 0.505 & 0.505 & $0 / 000$ & & & \\
\hline & VAG3 & 0.532 & 0.532 & & & & \\
\hline \multirow{2}{*}{$\begin{array}{l}\text { Taking notes and } \\
\text { remind of activities }\end{array}$} & YAD1 & 0.572 & 0.572 & & 3 & 90.546 & 0.745 \\
\hline & YAD2 & 0.412 & 0.412 & 0.000 & & & \\
\hline \multirow{3}{*}{$\begin{array}{l}\text { Inclusion of external } \\
\text { factors in the activity }\end{array}$} & LAH1 & 0.679 & 0.679 & & 6 & 66.652 & 0.825 \\
\hline & LAH2 & 0.672 & 0.672 & 0.000 & & & \\
\hline & LAH3 & 0.728 & 0.728 & & & & \\
\hline \multirow{3}{*}{$\begin{array}{c}\text { Doing activities in less } \\
\text { time (time } \\
\text { management) }\end{array}$} & MOD1 & 0.252 & - & & 9 & 114.210 & 0.657 \\
\hline & MOD2 & 0.623 & 0.623 & 0.000 & & & \\
\hline & MOD3 & 0.508 & 0.508 & & & & \\
\hline \multirow[t]{2}{*}{ Innovative suggestions } & PIS1 & 0.523 & 0.523 & & 5 & 75.215 & 0.0752 \\
\hline & PIS2 & 0.652 & 0.652 & 0.000 & & & \\
\hline
\end{tabular}




\begin{tabular}{|c|c|c|c|c|c|c|c|}
\hline Variable name & Items & $\begin{array}{c}\text { Factor } \\
\text { loadfirst stage }\end{array}$ & $\begin{array}{c}\text { Factor load } \\
\text { after removing } \\
\text { variables }\end{array}$ & $\begin{array}{c}\text { Significance } \\
\text { of Bartlett's } \\
\text { Test }\end{array}$ & $\begin{array}{l}\text { Degrees of } \\
\text { freedom }\end{array}$ & $\begin{array}{c}\text { Approximately } \\
2 \mathbf{2} x\end{array}$ & $\begin{array}{c}\text { KMO sampling } \\
\text { adequacy } \\
\text { criterion }\end{array}$ \\
\hline \multirow{3}{*}{$\begin{array}{c}\text { Create new fungal job } \\
\text { opportunities }\end{array}$} & FOR1 & 0.555 & 0.555 & & 6 & 82.112 & 0.0675 \\
\hline & FOR2 & 0.752 & 0.752 & 0.000 & & & \\
\hline & FOR3 & 0.453 & 0.453 & & & & \\
\hline \multirow{3}{*}{$\begin{array}{l}\text { Study and modeling } \\
\text { the work life of } \\
\text { successful people }\end{array}$} & MOT1 & 0.483 & 0.483 & & 6 & 59.456 & 0.0645 \\
\hline & MOT2 & 0.522 & 0.522 & 0.000 & & & \\
\hline & МОТ3 & 0.666 & 0.666 & & & & \\
\hline \multirow{3}{*}{$\begin{array}{l}\text { Sharing others in } \\
\text { interests and profits }\end{array}$} & SHA1 & 0.455 & 0.455 & & 9 & 87.241 & 0.0675 \\
\hline & SHA2 & 0.525 & 0.525 & 0.000 & & & \\
\hline & SHA3 & 0.654 & 0.654 & & & & \\
\hline \multirow{2}{*}{$\begin{array}{l}\text { Understanding the } \\
\text { different aspects of } \\
\text { Intrapreneurship }\end{array}$} & ASH1 & 0.325 & 0.325 & & 6 & 74.564 & 0.0752 \\
\hline & ASH2 & 0.404 & 0.404 & 0.000 & & & \\
\hline \multirow[t]{3}{*}{ Legitimate activities } & MASH1 & 0.612 & 0.612 & & 9 & 84.745 & 0.596 \\
\hline & MASH2 & 0.575 & 0.575 & 0.000 & & & \\
\hline & MASH3 & 0.456 & 0.456 & & & & \\
\hline
\end{tabular}

These behaviors are referred to below:

(1) Personality-based Intrapreneurial Behaviors: One of the main categories of interviewees from the present study is personality-based behaviors; this includes components; human and altruistic behavior; active listening; order and coordination; encouraging others to provide innovative designs, creating an atmosphere of empathy, communicating effectively with others (network behavior), prospecting, hoping for success, and performing a subsidiary work alongside the main work, Starburst insists that due to the large volumes of extraction information summarized below and some examples are given.

1-1) Ethical and philanthropic behavior: One of the extracted components of intrapreneurial behaviors in the organization is human and allegorical behaviors. In this regard, individuals expressed:

"... We have more rational behavior in our organization, ... rational behavior along with godly behavior, respect for colleagues along with respect for the rights of others ... We must deal with colleagues as human beings, not just cars, not just to exploit for our benefit, we have to deal with people around us, so things get better ... "

2-1) Active listening: Listening is active from other components extracted from the texts. One of the interviewees said:

"I usually listen to my ideas. Sometimes I say that confidence is not low, but I say to myself, if we can use the ideas of our colleagues, it's nice not only from colleagues inside the company but from outside people who have experience in the field we have to listen to our words and use it "

3-1) Order and Coordination: Another component of the intrapreneurial behaviors in organization, order and coordination. The interviewee says:

"Activities that are consistent with discipline will lead to profitable. The order of purpose targets the work and helps to improve the work. We usually go through discipline in doing things. "Order and coordination make us move and move together ..."

4-1) Encouraging others to provide innovative designs: Another component of intrapreneurial behavior in an organization that entrepreneurs referred to are:

"I usually encourage my colleagues to tell them everything about their work and how to do it, if they cannot be done, they will not be upset. You can get better ideas if you're wondering why this process is up to this. You can definitely find some great ideas. We changed several processes in one of our Dorsa factories and removed the process ...."

5.1 Creating an atmosphere of empathy: Entrepreneurs usually create an atmosphere of sympathy with other 
members of their organization in the workplace, in which one interviewee states:

"... empathy is an important factor in working with others, and we try to create empathy in our workplace ... Based on our company, we formed four sympathetic companies."

6-1) Communicating Effectively with others (Network communication): Other behaviors that entrepreneurs face in their work environment is to communicate effectively with others. They are members of different teams and groups, and they interact with others.

"Work cannot be left to God's way. People around us must be managed. human resource management is one of the most important activities. It is necessary to be active in different teams work ... It is necessary to communicate with colleagues for manpower management, especially in teamwork template and work in different teams .... I am a member of many different teams. I usually attend group meetings, and even after a meeting and outside the company, I'm in contact with some people in different groups. And we have a dialogue with them ...".

7-1) Future Enthusiasm: Future enterprise entrepreneurs, including the behavioral components mentioned:

"I always say that when it comes to my work, this will be better than that ... I think the future will be better ... I try to improve it ... I enjoy doing it but I feel it. The situation is not what I follow ... I think a lot of times in the future ... I can better be what I'm... It's made up of a new job and a new way. Let's draw the future for ourselves. And with the hope of reaching out to it ... I usually write down what I can do in the future, how I want to do it or what it's needed ..."

8-1) Hope for Success: Among other components of the behavior of entrepreneurs in the organization is the hope of success, in this connection an interviewer believes that the hope of success is also more important than the need for success:

"The feeling of success is also important, but in my country, including our company, we are more hopeful of success ... Our company was originally a startup, rather than a sense of success, hoping for success because we felt that we have succeeded no longer motivated. People are more motivated by the hope of success and, in my opinion, they are saturated with a feeling of success, and others need to succeed, but hope they will always try if they have ..."

9-1) peripheral alongside main work: Organizational entrepreneurs, their main focus is on the focus of a particular activity, but usually, along with that activity, they lower one to another subordinate activity:

"In our company, people's attitudes should be voluntary, even suggesting, alongside their own core work ... I, myself, usually think alongside the main activity that I am doing ..."

10-1) Persistence, patience, and insistence: Another component of intrapreneurial behavior in the workplace is interviewed:

"Sometimes, you must insist on what you feel is logical and correct, and if you cannot make a logical reason ... When one says he does not become my experience and it is not logical, it is not only experimental. We say that if we cannot give a reason ... on the same basis as our offer. We insist until the person brings a reason ... There were many places where we suggested that there might be too much to go about in another unit, for example, for examination. The offer is usually sent to the unit for which the offer is there, if the supervisor wants to confirm that he will be questioned ..."

(2) Effective intrapreneurial behaviors from the environment: The second main category of interviewees with organizational entrepreneurs is environmentally effective behaviors, which include 17 components of independent work in group work-learning and learning through training. Work - Using New Science and Technology Readiness to Accept Change - Combine Knowledge, Skill and Experience - Time to Deliver Problem - Learn Professional Work Skills - Monetize Activities - Taking notes and reminding activities - Taking into account the external factors of organization in doing business - Innovative suggestions - branch out new business opportunities - doing activities in a limited period of time (managing time) - sharing others with benefits and benefits - studying and A modeling of the working life of successful people - familiarity with various aspects of intrapreneurship - is a legitimate activity, which is referred to as examples due to the large volume of information:

1-2) Independent action in the form of group work: The components of the behavioral discovery of entrepreneurs in the organization, their autonomy while believing in teamwork and collective decision-making. In this regard, the interviewer says:

"... It's a great factor in the success of a team. If we think that teamwork is in line with the team, that's not right. I believe teamwork should be a fight. When I read Bill Gates's work, I saw that many times. He argued with the vice chairman loudly, but when it comes to a final result, the teamwork does not necessarily coincide. Everyone needs 
to say firmly, argue, talk to them, and then finally come to an end. The manager has made the final decision, so it's time for the work to be done ..."

2-2) Learning and teaching through work-based learning: Entrepreneurs are learning and remembering in the workplace. Interviewer says:

"I am learning in my ongoing activities ... the most important training is learning while working, and this should be permanent ... Education is also important. Learning the techniques of work takes place with education. We try to train and train others as well. "

3-2) Using New Science and Technology: Entrepreneurs in their work environment use new science and technology:

"There is nothing stagnant. From the past, everything in the world is moving fast forward, which must surely be the use of new things that we can do if we do not do it. To work quickly and profitably, we will have to do something new, new science, a new force and a new thought are necessary ... if you do not do this, you'll be back and you will not be there anymore ... our behavior must be new and different, and we will be different every day of our day than yesterday "

4-2) Readiness to accept changes: Among the behaviors of enterprise, entrepreneurs is to be prepared for accepting changes.

"The IT area changes day by day. Changes are occurring in all domains, but in the IT field, there is a more rapid change ... We used to work on $\mathrm{C}++$ Plus programming, but today we are starting out in a new environment like $\mathrm{x}$ We need to have this spirit and readiness to quickly accept the new conditions and not resist. "

5-2) Integrating knowledge, skills, and experience: Entrepreneurs use a combination of knowledge, skills, and experience in doing business:

"Academic and academic discussion is not totally scientific but it is a necessary platform for the implementation of the ideas and the work we want to do. In fact, having a university degree is not zero to $100 \%$ of work, but it can facilitate the work... people who have the idea but are deprive of skills are unfortunately not successful. For example, in our work, we have a computer science and programming science, but it is very important for human language and computer programming and a person cannot produce something himself, and there is the idea that the computer can do this. Therefore, the university debates must be but in practice, they should have experience and the combination of science and the operation was aimed at "

6-2) Time to resolve the problem: Among the activities that organizational entrepreneurs face in their work, time is spent solving the problem:

"One day my superiors called me to his office ... I went to his office, his mind was awfully busy with an issue ... I had a very sad problem ... I asked for help. What was the point? What was the problem? I said that there was a problem It's not that he's upset, I just told him it was fine, this happened because, from now on, we can think of the next solution. "

7-2) Learning Professional Skills: Organizational entrepreneurs will learn the skills they need in their work:

"... I have tried to learn new skills ... you want to take a map. You must be the master of the world of work. It is someone who has knowledge of it, who will be accounting, and the audit should have his own expertise, without having the skills at all It cannot succeed. "

8-2) Monetization activity: One of the components of entrepreneurship behavior is income-generating activity:

"Financial discussions are important in business. It's business, profit, and revenue. If we try to work, but we do not have a financial result, it is not worth working on it ... I always have financial and monetary consequences. I'm doing my best and trying to look at the financial implications. "

9-2) Taking notes and reminders of activities: Among the activities that organizational entrepreneurs do, take notes and reminders of activities:

"One has to work 16 hours, 8 hours to work in the work environment, and the house, which has 8 hours of rest, to think about his work ... I usually write down the things I want to do and write and review them and remind them. I'm making "

10-2) Taking into account the outside factors of the organization: Entrepreneurs also consider environmental factors outside the organization. In this regard, the interviewer states:

"... In production and manufacturing processes, the issue of dependence on macroeconomics and government is 
also important. We try to consider these factors in our work activities ... how much the social and economic conditions of the community can be rotated creating organizations to work in that environment and doing Intrapreneurial activity is very important. I also see the idea of a community. I also observe issues outside of the company. The rules and regulations of our tax information tax issues. I am raising the issues in these areas and I may also be consulting with friends and experienced people. "

11-2) Innovative suggestions: Among the behaviors that entrepreneurs face in the organization, they offer innovative suggestions:

"... We face every day with innovative suggestions from the thinking of the people who work. For example, the mechanic is suggesting whether to take the car now or fix it for another 10 days. So active listening to suggestions also leads to Innovative suggestions are made up of employees' dissatisfaction. "

12-2) branching out new job opportunities: Another component of the behavior of entrepreneurs is to create new business opportunities:

"monotonous and repetitive works are boring. In the workplace, I'm usually looking for new opportunities. Every day is a new day. We have to do something new. In our work, innovation is the first word, reaching a new model of work is satisfying for me ... new work is being done in the form of karma ... organizational creativity can, in turn, branch out new jobs and opportunities. "

13-2) Activities in a limited period of time (time management): Another activity that organizational entrepreneurs pay attention to is managing time and doing activities in a limited period of time:

"I'm trying to do things faster and through a limited period of time ... It's important to me. It's our goal to reduce the time gap and reduce the duration of the project."

14-2) Partnering others in the interests and benefits: Among the actions that corporate entrepreneurs do in their organization is partnering with others in the interests and benefits of activities that take place.

"We are ready to reduce our profit to our organization, but other profits are profitable. We are ready to make a profit in the short term but have a strong workforce, but fewer damages and more incentives, and ultimately increase our profits in the long run ..."

15-2) Study and modeling of the working life of successful people: Organizational entrepreneurs study and model the lives of successful people:

"My job was software. I liked to know the success of the successful people in my field of work, and I saw the history of Microsoft and the modeling of Bill Gates's life, dividing the dividends among his close friends, so we tried to make people become more involved in stock ... reading the life of successful people provides us with some useful ideas. By reading Bill Gates's book of life, I learned a lot of interesting things. It gives us an idea and provides a platform for our success. .. For example, Bill Gates was prospective, for example, having a slogan, when the computer was at the university, the motto was that in the near future anyone's desk should be a personal computer."

16-2) Understanding different types of entrepreneurship: Organizational entrepreneurs are trying to become familiar with different aspects of entrepreneurship:

"In my opinion, entrepreneurship is a general concept. Educational, service, production, and entrepreneurship have different meanings. Everything can be included in a category. It should be familiar with all aspects of entrepreneurship. Creation is not just saying that we have a career, we have a new way of engaging with entrepreneurship every day in our workplace. New basic materials, new processes, new customer recruitment, new market discoveries ... These are all the different aspects of entrepreneurship that they should know ..."

17-2) Legal and legal activity: The other components of the behavior of entrepreneurs in the organization are legal and legal. In this regard, the interviewer says:

".... And in this regard, I have customer service, whether material or spiritual ... I believe that my work should have both material and legal effect. It is right now that it is sacred and earning sacred legitimacy, but I personally do not legitimize some of my work like a dealership ..."

\section{Discussion}

Research has shown that most of the well-known world companies use their own specific human capital for organizational utilization. One of these specific features of human capital is the behavior and actions that human resources bring to the organization itself. While previous research has focused on factors affecting entrepreneurial behavior and entrepreneurial characteristics, the present study attempted to identify entrepreneurial behaviors 
(entrepreneurial activities and activities) in the organization. Hence, the purpose of this research is to discover the components of entrepreneurial behavior in the organization by designing the main question of "which are the components of entrepreneurial behavior in the organization?". In this research, we tried to explore the components of the entrepreneurial behavior in the organization by analyzing the content network. The network of themes is a good method for analyzing the content developed by Atride-Sterling (2001). What the theme network offers is a site-like map as the organizing principle and display method. The grid themes systematically regulate the basics (key codes and key points of the text) and the general themes (based on the principles that govern the text as a whole) based on the specific process. Unlike other methods, the grid of content is graphically and similar to the website, so that the idea of any hierarchy among them disappears. In this research, 238 basic themes and 27 themes were counted. Entrepreneurial behavior in the organization has two main categories, personality-based entrepreneurial behaviors and effective entrepreneurial behaviors from the environment, each of which has 10 and 17 inclusive themes, respectively, and each of the inclusive themes includes several basic themes. The results of this study, due to the novelty of the actual behavioral components of the interviewees, can greatly explain the entrepreneurial behaviors in the organization and provide a clear framework for identifying and promoting these behaviors in the organization.

\section{References}

Anton, J. J., \& Yao, D. A. (1995). Start-ups, spin-offs, and internal projects. J. Law Econ. Organ., 11, 362-378.

Audretsch, D. B. (2001). Research issues relating to structure, competition and performance of small technologybased firms. Small Bus. Econ., 16, 37-51.

Bedigian, L. (2011). "Can apple survive without Steve Jobs?" Forbes. Retrieved from http://www.forbes.com/sites/ benzingainsights/2011/08/25/can-apple-survive-without steve-jobs

Brown, M., \& Cregan, C. (2008). Organizational change cynicism: The role of employee involvemen. Journal of Human Resource Management, 47(4), 667-686.

Claycomb, C., Iyer, K., \& Germain, R. (2005). Predicting the level of B2B e-commerce in industrial organizations. Ind. Mark. Manage, 34(3), 221-234.

Davidsson, P. (2006). Nascent Intrapreneurship: empirical studies and developments. Foundations \& Trends in Intrapreneurship, 2(1), 1-76.

Elert, N., Andersson, F., \& Wennberg, K. (2015). The impact of Intrapreneurship education in high school on long-term Intrapreneurial. Journal of Economic Behavior \& Organization, 111(2015), 209-223.

Ergun, E. (2004). "Connecting the link between corporate Intrapreneurship and innovative performance, "Global Business and Technology Association Annual Conference Proceedings Book, July, pp. 259-265.

Feige, E. L. (1994). The Transition to a Market Economy in Russia: Property Rights, Mass Privatization and Stabilization PDF .(In Alexander, Gregory S.; Skąpska, Grażyna .A Fourth way?: privatization, property, and the emergence of new market economics.

Freeman, J., \& Engel, J. S. (2007). Models of innovation: startups and mature corporations. Calif. Manage. Rev. 50(1), 94-119.

Fry Fred (1993). Intrapreneurship: a planning approach. west publishing company.

Gholami, A., \& Bashlideh, K. (2011). Effectiveness of therapeutic spirituality on mental health of divorced women. Family Consultation and Psychotherapy Quarterly, 1(3), 331- 348. (Persian).

Govindarajan, V., \& Trimble, C. (2005). Building breakthrough businesses within established organizations. Harvard Business Review, 83(5), 58-68.

Gunther, M. (2010). 3M's innovation revival. CNN Money. Retrieved from http://money.cnn.com/2010/09/23/ news/companies/3m_innovation_revival.fortune/index.htm

Gupta, V. K. (2008). The impact of Intrapreneurial orientation on knowledge management in strategic alliances: Evidence from high technology SMEs, North Carolina: The Babson Intrapreneurship Confrence.

Helfat, C. E., \& Lieberman, M. B. (2002). The birth of capabilities: market entry and the importance of pre-history. Ind. Corp. change, 11, 725-760.

Kim, P. H., Aldrich, H. E., \& Keister, L. A. (2006). Access (not) denied: the impact of financial, human, and cultural capital on Intrapreneurial entry in the United States. Small Bus. Econ., 27(1), 5-22.

Klepper, S. (2001). Employee start-ups in high-tech industries. Ind. Corp. Change, 10, 639-674. 
Kuratko, D., Hornsby, J., \& Covin, J. (2015). Diagnosing a firm's internal environment for corporate Intrapreneurship. Kelley School of Business, Indiana University, 1309 E. Tenth Street, Bloomington, IN 47405-1701, U.S.A.

Kuratko, D. F., \& Goldsby, M. G. (2005). Managers corporate Enterpreneurial Actions and Job satisfaction. International Enterpreneurship and Management Journal, 1, 271-291.

Kuratko, D. F., Ireland, R. D., Covin, J. G., \& Hornsby, J. S. (2005). A model of middle-level managers' Intrapreneurial behavior. Entrep Theory Pract, 29(6), 699-716.

Kuratko, D. F., Goldsby, M. G., \& Hornsby, J. S. (2012). Innovation acceleration: Transforming organizational thinking. Upper Saddle River, NJ: Pearson/Prentice Hall.

Mazzarol, T., \& Reboud, S. (2006). The strategic decision making of entrepreneurs within small high innovator Firms. Int Entrep Management Journal, 2, 261-280.

Miller, D., \& Friesen, P. H. (1978). Archetypes of strategy formulation. Management Science, 24.

Mirela, X., \& Will, B. (2017). Institutional constraints and SME growth in post-communist Albania. Journal of Small Business and Enterprise Development, 19(4), 607-626

Morris, M. H., Kuratko, D. F., \& Covin, J. G. (2011). Corporate Intrapreneurship \& innovation (3rd ed.). Mason, $\mathrm{OH}$ : South- Western Cengage.

Munoz, P., \& Kimmitt, J. (2018). Intrapreneurship and the rest: The missing debate. Journal of Business Venturing Insights, 9, 100-106

Namey, E., Guest, G., Thairu, L., \& Johnson, L. (2007). Data Reduction Techniques for Large Qualitative Data Sets. In Guest G., \& MacQueen K. M. (Eds.), Handbook for Team Based Qualitative Research (pp. 137-162). United Kingdom: AltaMira Press.

Parker, S. C. (2011). Intrapreneurship or Intrapreneurship? Journal of Business Venturing, 26(2011).

Zampetakis, L. A., \& Moustakis, V. (2007). Intrapreneurial behavior in the Greek public sector. International Journal of Intrapreneurial Behavior, 13(1), 38-19.

Zucker, L. G., Darby, M. R., \& Brewer, M. B. (1998). Intellectual human capital and the birth of US biotechnology enterprises. Am. Econ. Rev., 88(1), 290-306.

\section{Copyrights}

Copyright for this article is retained by the author(s), with first publication rights granted to the journal.

This is an open-access article distributed under the terms and conditions of the Creative Commons Attribution license (http://creativecommons.org/licenses/by/4.0/). 